\section{Dental therapy in the United Kingdom: part 1. Developments in therapists' training and role}

\author{
J. S. Rowbotham, ${ }^{1}$ J. H. Godson, ${ }^{2}$ S. A. Williams, ${ }^{3}$ J. I. Csikar ${ }^{4}$ \\ and S. Bradley
}

VERIFIABLE CPD PAPER
IN BRIEF
- This paper outlines the history and development of dental therapy within the UK.
- It describes the recent expansion in the number of dental therapy training places and details of dental therapy schools.
- It explores the clinical remit of dental therapists, the expanded range of clinical settings in which they currently work and their future importance in providing added value to the dental team.

The number of students entering training for dental therapy has been increasing rapidly over the last few years. In practice, the scope of their work has increased, both in terms of permitted duties and their range of clinical settings. The possibilities for dental practitioners to work with therapists is therefore increasing, so it is important for them to be clear about therapists' potential capacity to provide added value to the dental team. This paper, which is the first of four covering aspects of dental therapy in the UK, traces the history of dental therapy together with the development of therapists' training opportunities and emerging competencies, up to the present. The subsequent three papers will describe aspects of a survey of dental therapists undertaken in late 2006.

\section{THE EARLY YEARS}

There are now increasing numbers of students entering training for dental therapy in the UK. Dental therapists could be considered by the general public and dental profession as a new additional team member since their introduction to general

\section{DENTAL THERAPY IN THE UNITED KINGDOM \\ 1. Development in therapists' training and role \\ 2. A survey of reported working practices \\ 3. Financial aspects of current working practices \\ 4. Teamwork - is it working for dental therapists?}

'Dental Therapist/Principal Tutor, Programme of Dental Hygiene and Dental Therapy, Leeds Dental Institute, Clarendon Way, Leeds, LS2 9LU; ${ }^{2}$ Honorary Lecturer, Dental Public Health, Leeds Dental Institute/Consultant in Dental Public Health, NHS Bradford and Airedale, Douglas Mill, Bowling Old Lane, Bradford, BD5 7JR; ${ }^{3}$ Emeritus Professor in Oral Health Services Research, Dental Public Health, Leeds Dental Institute, Clarendon Way, Leeds, LS2 9LU; ${ }^{4 *}$ Researcher, Dental Public Health, Leeds Dental Institute/Senior Public Health Manager, NHS Bradford and Airedale, Douglas Mill, Bowling Old Lane, Bradford, BD5 7JR; ${ }^{5}$ General Dental Practitioner/ PCT Dental Adviser, Primecare Oral Health Services, Bedale Health Centre, Sussex Street, Bedale, North Yorkshire, DL8 $2 \mathrm{AH}$

${ }^{*}$ Correspondence to: Ms Julia Csikar

Email: j.i.csikar@leeds.ac.uk

\section{Refereed Paper}

Accepted 8 April 2009

DOI: $110.1038 /$ sj.bdj.2009.900

${ }^{\circledR}$ British Dental Journal 2009; 207: 355-359 dental practice in 2002. ${ }^{1}$ In fact historical evidence reveals that there were 'dental dressers' performing equivalent roles almost a century ago.

As early as 1909, local authorities, including those in Bradford, Cambridge, Chester, Coventry, Sheffield and Norwich, had already started to lay the foundations for a School Dental Service. ${ }^{2}$ However, during the First World War it was difficult to recruit dentists, and there were high levels of dental caries in children requiring attention.-5 Therefore, some authorities experimented with the introduction of 'dental dressers'. These were women who worked with a dentist and were trained to clean, fill and extract the teeth of school children under immediate supervision of a dentist. ${ }^{2,5}$ By 1923, Derbyshire, Sheffield and Shropshire Education Authorities were employing dressers. In Derbyshire, there were two dressers working with one dentist. On this basis, it was argued that dressers cost less to train (and employ), and that such teams substantially improved the dentist's output. ${ }^{5}$

The introduction of dressers was met with substantial opposition from the dental profession. ${ }^{4}$ In 1923 the Ministry of Health ordered that the Derbyshire scheme be abolished, under the powers of the 1921 Dentist Act. ${ }^{5}$ In 1932 there was a further amendment which restricted the scope of the dressers' work to scaling and polishing, ${ }^{5}$ although they were not completely abolished until 1942.
By the end of the Second World War, the government again recognised the significant amount of oral disease in the country. While the School Dental Service had been largely neglected during the interwar years, ${ }^{4}$ the future of this service was threatened in 1948 with the introduction of the new National Health Service, when large numbers of school dentists, with the prospect of better pay, moved into general practice. ${ }^{5}$ With the possibility of disintegration of the School Dental Service, the government looked to New Zealand for inspiration.

\section{NEW ZEALAND DENTAL NURSES}

New Zealand had been facing a similar problem to that of the UK and had developed a model similar to 'dental dressers'. In 1921 the first School for Dental Nurses had opened in Wellington. ${ }^{5}$ Women were trained to carry out a range of dental duties including diagnosis of dental disease and treatment planning for deciduous teeth. Some children who were seen regularly by New Zealand dental nurses might not see a dentist until the age of 13 . By the 1950s two more schools had opened in Auckland and Christchurch. This model has been subsequently used and developed by Australia, Canada, Malaysia, Sri Lanka, The Netherlands and many more countries worldwide.

A government group was sent out from the UK to assess the New Zealand model. 
In 1951, they reported back to the effect that the nurses provided a high standard of treatment. There was a significant degree of controversy and opposition from dentists to the idea of introducing this type of clinical worker into the UK but the Dentists Bill was finally passed in 1957 . The newly created General Dental Council (GDC) was then instructed to carry out an experimental scheme and it was the GDC itself that was to set the conditions under which the newly emerging 'dental auxiliaries' would work.

\section{THE NEW CROSS ERA}

The new dental auxiliaries (as they were originally known) would only be allowed to work in the public services (for example, salaried - hospital and school dental service) but not in general practice. They would work to a prescription from a dentist and would not be permitted to discharge their patient without a final inspection from the dentist. ${ }^{5}$ They were allowed to carry out 'simple fillings' and extraction of deciduous teeth. Compared to the New Zealand nurses, who additionally performed independent diagnosis and treatment planning for young children, their clinical practice was extremely restricted.

In 1959 the first school for dental auxiliaries was opened at New Cross Hospital in South London. ${ }^{5}$ The school admitted 60 female students per year for a two-year course. Entry requirements were five GCEs. Students were chosen from across the UK in the expectation that they would return to their home towns on completion of their training. However, after two years the government realised this was not happening and made students, parents and guardians sign to say they would be prepared to work anywhere in the UK as a condition of acceptance on the course. However, this was impossible to enforce. By 1965 it was considered that the new dental auxiliary was making a valuable contribution to the dental service ${ }^{5}$ and the Ancillary Dental Workers Regulation established them as part of the dental team.

\section{AN ERA OF CHANGE: 1980s ONWARDS}

New Cross continued to train approximately 60 students per year. In 1979 the Royal Commission on the NHS ${ }^{6}$ recommended that there should be an expansion of training facilities for dental therapists and the establishment of two new schools. The Nuffield Foundation Inquiry into dental education in $1980^{7}$ was also positive and anticipated changes in duties to allow therapists to become even more useful members of the dental team.

Despite these favourable reviews, in 1981 the Report of the Dental Strategy Review Group $^{8}$ recommended the closure of New Cross along with a $10 \%$ reduction in dental undergraduate places nationwide. In 1983 New Cross closed.

However, the training of a small number of dental therapists continued at the Royal London Hospital. A combined course for eight students offered dual qualification as a dental therapist and dental hygienist (the current roles of these groups can be seen in Table 1). Unlike New Cross, where students were trained in isolation from the rest of the dental team, students were now integrated with undergraduate dental students for part of their two-year course.

Unfortunately during the 1980s employment opportunities for dental therapists were limited as they were restricted to employment within hospitals and community placements and few positions were available. However, there was plenty of demand for dental hygienists, who could also work in general dental practice. A number of 'New Cross' therapists therefore took the opportunity of attending shortened courses to obtain the hygienist qualification. This gave them the option of working in general practice as a hygienist where potential earnings were far greater.

In 1993, The Nuffield Report into the Education and Training of Dental Auxiliaries ${ }^{5}$ was published. The report made significant recommendations for all clinical dental auxiliaries, including dental therapists, dental hygienists and dental surgery assistants, later called professionals complimentary to dentistry (PCDs) and more recently, dental care professionals (DCPs). With regard to dental therapists, the report recommended that they expand their remit and, most importantly, that the restrictions regarding workplace should be lifted and therapists permitted to work in general dental practice in the future. In 1998, the GDC Dental Auxiliary Review Group ${ }^{9}$ published their report, which further endorsed these recommendations.
Table 1 Dental therapists' (*hygienist) permitted duties currently included in the curriculum 2004 ${ }^{10}$

*Record and monitor disease

*Plan the delivery of treatment

*Treat adults and children

${ }^{*}$ Give oral hygiene instruction, diet advice and smoking cessation

${ }^{*}$ Carry out supragingival and subgingival scaling

*Root surface debridement

*Fluoride application and anti microbial therapy

*Fissure sealants

*Take, process and interpret radiographs

${ }^{*}$ Give local infiltration and Inferior Dental Block anaesthesia

* Refer patients to other healthcare professionals

*Take impressions

*Place Rubber dam

*Recement crowns with temporary dressing if removed during treatment

Restorations in permanent dentition without

pulpal involvement

Restorations in deciduous dentition

Pulpotomies on deciduous dentition

Placement of preformed stainless steel crowns on deciduous dentition

Extraction of deciduous teeth under local anaesthetic

Additional skills which dental therapists (*hygienists) could develop during their

careers have been set out by the GDC within 'Scope of practice'25

*Tooth whitening

*Prescribe radiographs

${ }^{*}$ Administer inhalation sedation

*Removal of sutures

Vary the detail, but not the direction of a treatment plan

\section{EXPANSION OF TRAINING}

The Royal London Hospital continued to train eight students per year as dually qualified dental therapists and dental hygienists. Expansion in therapy training began in 1996 when Cardiff Dental Hospital started a dental therapy course funded by the Welsh Office. Qualified dental nurses working within the community dental services were recruited for the first course. They were funded throughout the course by their respective community dental services and on qualification returned to work there. The following year, the 


\section{Table 2 Details of current UK dental therapy schools (dual qualification) August 2007}

\begin{tabular}{|c|c|c|c|c|c|c|c|}
\hline School & $\begin{array}{l}\text { Course } \\
\text { started }\end{array}$ & Award & Entry qualifications & $\begin{array}{l}\text { Length } \\
\text { of course }\end{array}$ & $\begin{array}{l}\text { Tuition } \\
\text { fees }\end{array}$ & $\begin{array}{l}\text { Financial } \\
\text { support }\end{array}$ & $\begin{array}{l}\text { Students } \\
\text { per year }\end{array}$ \\
\hline Birmingham & 2004 & $\begin{array}{l}\text { BSc in Dental Hygiene and } \\
\text { Dental Therapy }\end{array}$ & $\begin{array}{l}3 \text { 'A' levels grades } B B C \\
2 \text { 'A' levels + qualified dental nurse }\end{array}$ & 3 years & Nil & NHS bursary & 25 \\
\hline Bristol & 2007 & $\begin{array}{l}\text { Diploma in Dental Hygiene } \\
\text { and Dental Therapy } \\
\text { Diploma in Dental Therapy } \\
\text { (one off course) }\end{array}$ & $\begin{array}{l}2 \text { 'A' levels } \\
\text { Qualified dental nurse + Biology 'A' level } \\
\text { Qualified dental hygienist }\end{array}$ & $\begin{array}{l}27 \\
\text { months } \\
1 \text { year } \\
\text { full time }\end{array}$ & $\begin{array}{l}\text { Nil } \\
\text { Nil }\end{array}$ & $\begin{array}{l}\text { NHS bursary } \\
\text { Bursary }\end{array}$ & $\begin{array}{l}12 \\
6\end{array}$ \\
\hline Cardiff & 1996 & Diploma in Dental Therapy & Qualified dental nurse or 2 ' $A$ ' levels & 2 years & Nil & NHS bursary & 9 \\
\hline Dundee & 2004 & BSc in Oral Health Sciences & UCAS 240 points & 3 years & Nil & Grant & 10 \\
\hline $\begin{array}{l}\text { Edinburgh } \\
\text { School of } \\
\text { Hygiene } \\
\text { Therapy }\end{array}$ & 2006 & $\begin{array}{l}\text { Diploma in Dental Hygiene } \\
\text { and Dental Therapy }\end{array}$ & 3 Scottish Highers +5 standards & & Nil & Grant & $\begin{array}{l}4 \\
\text { (increasing } \\
\text { to 6) }\end{array}$ \\
\hline $\begin{array}{l}\text { Edinburgh } \\
\text { University }\end{array}$ & $2005-2007$ & Diploma in Dental Therapy & Qualified dental hygienist & $\begin{array}{l}3 \text { days a } \\
\text { week for } \\
36 \text { weeks }\end{array}$ & Nil & No & $\begin{array}{l}4 \\
\text { (increasing } \\
\text { to 10) }\end{array}$ \\
\hline Glasgow & 2003 & $\begin{array}{l}\text { Diploma in Dental Hygiene } \\
\text { and Dental Therapy }\end{array}$ & 3 Scottish Highers + 5 standards & $\begin{array}{l}27 \\
\text { months }\end{array}$ & Nil & Grant & 10 \\
\hline Leeds & 2001 & $\begin{array}{l}\text { Graduate Diploma in Dental } \\
\text { Hygiene and Dental Therapy }\end{array}$ & $\begin{array}{l}\text { Biology 'A' level + qualified dental nurse } \\
2 \text { 'A' levels, biology }+1 \text { other } \\
\text { Access course }\end{array}$ & $\begin{array}{l}27 \\
\text { months }\end{array}$ & Nil & NHS bursary & 24 \\
\hline $\begin{array}{l}\text { Liverpool } \\
\text { (outreach sites: } \\
\text { Blackburn } \\
\text { Crewe } \\
\text { Lancaster) }\end{array}$ & 2004 & $\begin{array}{l}\text { Combined Dental Hygiene } \\
\text { and Dental Therapy }\end{array}$ & $\begin{array}{l}2 \text { 'A' levels, } 1 \text { science related } \\
\text { Qualified dental nurse }\end{array}$ & $\begin{array}{l}27 \\
\text { months }\end{array}$ & Nil & NHS bursary & 24 \\
\hline $\begin{array}{l}\text { London: } \\
\text { Eastman } \\
\text { Dental Hospital } \\
\text { UCLH } \\
\text { Foundation } \\
\text { Trust }\end{array}$ & 1998 & $\begin{array}{l}\text { Diploma in Dental Hygiene } \\
\text { and Dental Therapy }\end{array}$ & $\begin{array}{l}2 \text { 'A' levels } \\
\text { Qualified dental nurse }\end{array}$ & $\begin{array}{l}27 \\
\text { months }\end{array}$ & Nil & NHS bursary & 10 \\
\hline $\begin{array}{l}\text { London: } \\
\text { Guys, Kings } \\
\text { \& St Thomas' }\end{array}$ & 2004 & $\begin{array}{l}\text { Diploma in Dental Hygiene } \\
\text { and Dental Therapy }\end{array}$ & $\begin{array}{l}\text { Qualified dental nurse } \\
2 \text { 'A' levels grade } C \text { or above }\end{array}$ & $\begin{array}{l}27 \\
\text { months }\end{array}$ & $\begin{array}{l}\text { Nil (no } \\
\text { longer } \\
\text { univer- } \\
\text { sity fees) }\end{array}$ & NHS bursary & 40 \\
\hline $\begin{array}{l}\text { London: } \\
\text { Barts and } \\
\text { the London }\end{array}$ & 1983 & $\begin{array}{l}\text { Diploma in Dental Hygiene } \\
\text { and Dental Therapy }\end{array}$ & $\begin{array}{l}\text { Qualified dental nurse }+ \text { AS level } \\
\text { biology or human biology } \\
2 \text { 'A' levels } 1 \text { biology }\end{array}$ & $\begin{array}{l}27 \\
\text { months }\end{array}$ & Nil & NHS bursary & 12 \\
\hline Manchester & 2003 & BSc in Oral Health Sciences & $\begin{array}{l}\text { UCAS entry } 2 \text { 'A' levels } \\
\text { (from } 20083 \text { 'A' levels) }\end{array}$ & 3 years & $\begin{array}{l}\text { Standard } \\
\text { tuition } \\
\text { fees }\end{array}$ & Student loan & 12 \\
\hline $\begin{array}{l}\text { Greater } \\
\text { Manchester, } \\
\text { Salford }\end{array}$ & 2005 & $\begin{array}{l}\text { Diploma in Dental } \\
\text { Hygiene and Diploma } \\
\text { in Dental Therapy }\end{array}$ & $\begin{array}{l}\text { Qualified dental nurse } \\
+1 \text { post qualification } \\
2 \text { 'A' levels, } 1 \text { science-based }\end{array}$ & $\begin{array}{l}27 \\
\text { months }\end{array}$ & Nil & NHS bursary & 10 \\
\hline Newcastle & 2006 & $\begin{array}{l}\text { Diploma in Dental Hygiene } \\
\text { and Dental Therapy }\end{array}$ & $\begin{array}{l}\text { Biology 'A' level }+ \text { qualified dental nurse } \\
2 \text { 'A' levels, biology }+1 \text { other }\end{array}$ & $\begin{array}{l}27 \\
\text { months }\end{array}$ & Nil & NHS bursary & 10 \\
\hline Portsmouth & 2004 & $\begin{array}{l}\text { BSc in Dental Hygiene and } \\
\text { Dental Therapy }\end{array}$ & UCAS 240 points & 3 years & Nil & NHS bursary & 24 \\
\hline Sheffield & 1996 & $\begin{array}{l}\text { Diploma in Dental Hygiene } \\
\text { and Dental Therapy }\end{array}$ & $\begin{array}{l}\text { Qualified dental nurse }+2 \text { post } \\
\text { qualifications } \\
2 \text { 'A' levels, } 1 \text { science or health related }\end{array}$ & $\begin{array}{l}27 \\
\text { months }\end{array}$ & Nil & NHS bursary & 30 \\
\hline
\end{tabular}


intake was opened up to students from the rest of the UK.

The Charles Clifford Dental Hospital, Sheffield, also started a therapy course in 1996 offering a combined course similar to that operating at the Royal London Hospital. Recruitment opportunities for dental therapy posts were relatively few and so by offering the dual qualification, it provided the potential for the graduates to work in general practice as hygienists. Dental hygienists also had job opportunities overseas. Unlike dental therapists, dental hygienist posts do exist in some European countries and this gave them the opportunity to work, for instance, within the EU. UK dental therapists have very limited opportunities to work elsewhere. Due to the differences in their duties, they may require additional assessment before working abroad.

Since 1996, the remaining dental hygiene schools have gradually begun to offer dental therapy as a combined course or as a separate qualification (Table 2). Liverpool University was the first to introduce a parttime course for dental hygienists to train as dental therapists. They recruited eight students per year for a two-year course. Running a part-time course enabled the hygienists to stay in employment while completing their training. All clinical work was carried out in outreach placements in community clinics.

A major change for the training establishments occurred around this time. The GDC had stepped down as the awarding body and the schools anticipated that the universities might take on this role. Many therapy schools have now made a successful move to a full university course. The GDC continues to ensure that educational providers meet the high standards required and to maintain a register for dental therapists as part of the Dental Care Professional (DCP) Register.

Two courses in Liverpool and Greater Manchester started training dental therapists away from dental schools. The unique feature of these courses is that all clinical training takes place in outreach placements, within community clinics and general dental practices.

\section{Degree courses}

In September 2000, the first degree course was introduced at the University of
Manchester. This is a three-year course leading to a BSc in Oral Health Science for the successful candidates. A degree is awarded an additional 40 academic credits, making a total of 360 credits, compared to the graduate diploma which has 320. However, the GDC ensures all students reach the same required clinical standard on graduation. Since then a number of schools have converted to a degree qualification.

\section{CLINICAL ROLE OF A DENTAL THERAPIST}

The GDC recommended that therapists be permitted to work in all sectors of dentistry, including general dental practice, in 1999. This was approved from 1 July 2002. At the same time, extended duties were added to their potential remit.

In 2004 the GDC published a curricula framework for the training of DCPs. ${ }^{10}$ At present all schools are regularly inspected by the GDC as part of quality assurance, ensuring they are all teaching to the published guidelines. Therefore, newly qualifying students will only be competent in the procedures as stated in the curricula (Table 1), previously termed 'permitted duties'.

The latest developments to impact on dental therapist working practice occurred in July 2006. The new GDC standards, 'Principals of dental team working' ${ }^{1}$ state that DCPs can carry out treatment if they are sure they are trained and competent to do it. Hence, therapists are no longer required to work to a specific remit, but as long as they are trained and competent, they can carry out any specific procedure. This has caused a lot of confusion among the dental profession as a whole and more clarity is needed regarding the context of any extra training to develop additional competencies. ${ }^{11}$ In response to these concerns the GDC has launched a 'scope of practice consultation.' ${ }^{12}$ The focus of the consultation is to protect the best interests of patients by developing greater clarity about the skills expected of a registrant on qualification, those they can develop, and those that should be reserved for other groups.

\section{Developing role in primary dental care}

As part of the government initiative to improve access to NHS care, a number of therapists were employed within personal dental service (PDS) schemes. ${ }^{13-15}$ The PDS was initiated to test an alternative delivery system of dental services, including the employment of dental therapists within dental practices. ${ }^{16}$ The PDS allowed therapists to work alongside general dental practitioners. It is argued that therapists working in NHS practice in an area of social deprivation with unmet need and lower levels of dental manpower can be a powerful boost to team working. ${ }^{17}$ While this vision may be limited by the numbers of therapists available, the situation is improving as more therapists are graduating. Since the changes in 2006, dental therapists can also own practices and employ other dental professionals.

A published review of four PDS pilots in the North West of England representing a range of practice profiles found that none of the practices were able to cover the cost of the salary of the dental therapist, dental nurse and practice overheads on the basis of the then current general dental service (GDS) fee scale. ${ }^{16}$ This calculation could not take account of the longer-term potential health gain associated with the preventive role of the therapist or the increased productivity of the dental team as dentists' freed capacity may be used to complete more complex clinical procedures with potential increased remunerative capability. However, the payment arrangements in NHS general dental practice have now changed.

A new dental contract was introduced in the NHS in England and Wales in April $2006 .{ }^{18}$ This contract is monitored on targets for units of dental activity (UDAs). 'Providers' (for example, the dental practice contract holders) are set annual targets and this has become the new contract currency. This arrangement has presented some opportunities for therapists who are in a position to generate UDAs, while hygienists are less able to do so. For example, if a dentist examines a patient and prescribes treatment, one UDA will have been earned by the dentist. If that patient also requires 'Band 2 treatment' that will usually fall within the remit of the therapist. As a result, three UDAs will have been earned in total, two by the therapist and one by the dentist. Another factor to consider is that of increased productivity. Once the patient has been referred to the therapist for routine care, the dentist is available to 
spend time doing more complex treatment and/or seeing private patients, while the therapist is working. This issue will also apply to hygienists, although the scope for their treatment will be more limited.

If the dental therapist expands the practice capacity for NHS treatment and prevention beyond that of the existing dentists, growth money would need to be allowed for in the contract. ${ }^{16}$ A therapist may, however, replace a dentist as long as there is sufficient capacity within the practice to complete the treatment required that is beyond the competence of the therapist and so be funded from within the contract value. There is insufficient evidence to determine whether or not a therapist working in practice within the new contract would be self-financing, but they could provide the opportunity for the dental practitioner to spend time treating other patients on a private basis. ${ }^{19}$

As long ago as 1982, the majority of dental practitioners surveyed could perceive themselves as head of a dental team delegating simple tasks. ${ }^{20}$ In effect, the role is more complex than this, including being a team co-ordinator and primary decision maker. ${ }^{21}$ The supervising dentist clearly needs to have teaching and management skills, in order to delegate an appropriate range of tasks for therapists to be effective and efficient members of the dental team. ${ }^{22}$

\section{THE FUTURE}

There has been a significant increase in the number of qualified dental therapists entering the profession each year. In 1985 there were eight students qualifying per year and now there are approximately 240. Most of the dental hygiene schools are now offering the combined course, providing greater potential flexibility as a hygienist and as a therapist. This increased capacity in the dental workforce offers the potential for improved scope and output of NHS care, including preventive care. As with dental hygienists, larger group practices may be best placed to employ a therapist. ${ }^{17}$

The expansion in dental therapy training opportunities has now been followed by the recent increases in dental undergraduate places. It is therefore crucial that all this training investment is well managed through workforce planning in the longer term and can enable provision of dental services according to the diversity of need. In addition to the existing courses, a new hygiene therapy course commenced in Scotland over two sites (Dumfries and Inverness) in September 2008. The current need for therapists to work to a dentist's treatment plan requires dentists' awareness and acceptance of the potential of that role. ${ }^{11,23}$ The clinical responsibilities of the dentist vis-à-vis that of the therapist must be clear and complementary and will benefit from a fusion of parallel and integrated training opportunities, especially where there are learning opportunities under the same roof. In the future, the dentist undergraduate workforce could expect to build up leadership, management and supervisory talents as team co-ordinators, as well as developing postgraduate specialist skills. The vision of a dental team where each member has 'mutual respect, trust and understanding of their respective roles and a genuine desire to embrace fully the science and art of teamwork ${ }^{24}$ is the ultimate goal.

This study was funded by the NHS R\&D Primary Dental Care Programme.

1. General Dental Council. Principles of dental team working. London: GDC, 2006.

2. Gelbier S. 125 years of developments in dentistry, 1880-2005. Part 6: general and specialist practice. Br Dent J 2005; 199: 685-688.

3. Woolgrove J, Boyles J. Operating dental auxiliaries in the United Kingdom - a review. Community Dent Health 1984; 1: 93-99.

4. Welshman J. Dental health as a neglected issue in medical history: the school dental service in England and Wales, 1900-40. Med Hist 1998; 42: 306-327.
5. The Nuffield Institute. The education and training of personnel auxiliary to dentistry. London: The Nuffield Institute, 1993.

6. Royal Commission on the National Health Service, London. 1979.

7. The Nuffield Institute. An inquiry into dental education. A report to the Nuffield Foundation. London: The Nuffield Institute, 1980.

8. Dental Strategy Review Group. Towards better dental health: quidelines for the future. London: Department of Health, 1981.

9. Dental Auxiliary Review Group. Professions complementary to dentistry. London: GDC, 1998.

10. General Dental Council. Developing the dental team Curricula frameworks for registerable qualifications for professionals complementary to dentistry (PCDs). London: GDC, 2004.

11. Ross M K, Ibbetson R J, Turner S. The acceptability of dually-qualified dental hygienist-therapists to general dental practitioners in South-East Scotland. Br Dent J 2007; 202: E8.

12. General Dental Council. Scope of practice consultation webpage. http://www. gdc-uk.org/News+publications+and+events Consultations/Closed+consultations/ Scope+of+Practice+Consultation.htm (accessed 24 September 2009).

13. Department of Health. Modernising NHS dentistry; implementing the NHS plan. London: Department of Health, 2000.

14. Goodwin N, Morris A J M, Hill K B et al. National evaluation of personal dental services (PDS) pilots: main findings and policy implications. Br Dent J 2003: 195: 640-643.

15. Ward P. The changing skill mix - experiences on the introduction of the dental therapist into general dental practice. Br Dent J 2006; 200: 193-197.

16. Harris $R$, Burnside $G$. The role of dental therapists working in four personal dental service pilots: type of patients seen, work undertaken and cost-effectiveness within the context of the dental practice. Br Dent J 2004; 197: 491-496.

17. Gallagher J L, Wright D A. General dental practitioners' knowledge of and attitude towards the employment of dental therapists in general practice. Br Dent J 2003; 194: 37-41.

18. National Health Service. The National Health Service (General Dental Services Contracts) Regulations. London: HMSO, 2005

19. Harris R V, Haycox A. The role of team dentistry in improving access to dental care in the UK. Br Dent J 2001; 190: 353-356.

20. Woolgrove J, Harris R. Attitudes of dentists towards delegation. Br Dent J 1982; 153: 339-340.

21. Hay I S, Batchelor PA. The future role of dental therapists in the UK: a survey of district dental officers and general dental practitioners in England and Wales. Br Dent J 1993; 175: 61-65.

22. Douglass C W, Lipscomb J. Expanded function dental auxiliaries: potential for the supply of dental services in a national dental program. J Dent Educ 1979; 43: 556-567.

23. Jones G, Devalia R, Hunter L. Attitudes of general dental practitioners in Wales towards employing dental hygienist-therapists. Br Dent J 2007; 203: E19

24. Seward M. PCD - what's in a name? Br Dent J 1999 187: 1 .

25. General Dental Council. Scope of practice. London: GDC, 2009. 